\title{
Ana-Maria Parasca
}

\section{The Sense of Otherness in Kate's Morton Novels}

\begin{abstract}
My paper tries to bridge the gap between Neo-Gothic realities of now and Gothic potentialities of the last century, using both the theoretical background proposed by critics and an analysis on Kate's Morton novels. The afterlife of the Gothic in Kate Morton's works provides a prolific landscape for exploring the legacies of the past and its burdens on the present. Kate Morton's writings play on circularity, blanks and fragmentation, in such a way that assembling all pieces together will not only reveal some secrets but will also solve the way out of the labyrinth. All her works allude to the myth of the Minotaur, projecting mysteries that need to be solved by assembling all the fragmented narratives.
\end{abstract}

Keywords: Neo-Gothic; Labyrinth; Kate Morton; Haunted House; Revival of the Past; Otherness.

\section{ANA-Maria Parasca}

Babeș-Bolyai University, Cluj, Romania anamariaparasca@yahoo.com

DOI: 10.24193/cechinox.2018.35.16

\section{Neo-Gothic as an Expression of the Otherness}

1 eo-Gothic has not yet acquired a clear tive on how Gothic has developed so far in contemporary art, but also how this new mythos of Gothic moves the concept of otherness from the background to the foreground. In Art of Darkness A Poetics of Gothic, Anne Williams includes under the umbrella of "otherness" a series of Gothic symbols that have developed in the present as being the primary factors that led up to the development of some new specific characteristic of this genre: "the supposedly irrational, the ambiguous, the unenlightened, the chaotic, the dark, the hidden, the secret."

The afterlife of the Gothic in Kate Morton's works provides a prolific landscape for exploring the legacies of the past and its burdens on the present by making recourse to some of the characteristics Catherine Spooner acknowledges in her study on Contemporary Gothic, such as: "the radically provisional or divided nature of the self; the construction of peoples or individuals as monstrous or 'other'; the preoccupation with bodies that are modified, grotesque or diseased."2 
The Gothic renaissance is the socalled Neo-Gothic, a cultural trend that revives the Gothic by appealing to the old themes the Gothic genre encapsulated: physical and psychical degeneration, mental alienation, trauma and fragmented identities, fear of the inhuman, of the otherness and of the unknown, a sense of catastrophe and apocalypse. The themes approached in contemporary gothic texts are as pertinent to the present as they were to the past centuries.

Following the same pattern in defining this new genre, Lynda Dryden plays on one of Karl's Beckson theories, which complements Spooner's conceptualization of neo-Gothic, arguing that cultural trends, such as Victorianism and rising Modernism, were moving at the same time into antithetical directions, both of which were critical to the direction that the novel was to take over the next century. ${ }^{3}$

The rejected otherness Anne Williams identifies in her study applies to all of Morton's novels, particularly by reintegrating the mad woman, who dwells within the house itself. The hidden and the secret are revealed between the walls of every house, representing at the same time the prevalent motif which stages the haunted self.

Kate Morton's writings play on circularity, blanks and fragmentation, in such a way that assembling all pieces together will not only reveal some secrets but will also find the way out of the labyrinth. All her works allude to the myth of the Minotaur, projecting mysteries that need to be solved by assembling all the fragmented narratives.

At first it might seem that Gothic elements are obvious in Morton's novels, since the author provides an inventory of familiar Gothic elements: a heroine willing to unravel some secrets, an abandoned or long-forgotten house and a labyrinth that needs to be discovered in order to enable the protagonist to find a way out of it.

There is much more to these novels, however, than either houses haunted by secrets or mysterious labyrinths. Morton's texts deal with a variety of themes as pertinent to contemporary culture as they were to past centuries. Some of these themes reflect what Catherine Spooner exemplifies in her study: the legacies of the past and its burdens on the present; the radically provisional or divided nature of the self; the construction of commiunities or individuals as monstrous or 'other'; the preoccupation with bodies that are modified, grotesque or diseased. ${ }^{4}$

The notion of identity that needs to be completed by remaking the self as monstrous supplements her theory and allows us to apply this concept to Morton's novels. The retrieval of Gothic motifs in this literature follows the ultimate twist, with readers being entrapped in a haunting mystery that has apparently no end.

Kate Morton's literary activity in the present is regarded as an ideological part of new Gothic literature. It may be argued that this author's literature fails to take into consideration one of the most prolific forms of Gothic, encapsulated by the concept of terror. In Morton's novels, terror expresses itself through what Maria Beville identifies as the characteristics of Gothic postmodernism, "unreal and indefinable and this is apart from the obvious terrors of living, alienated in our postmodern world of violence and political terrors. Postmodernism and more specifically, Gothic postmodernist literature has many terrifying 
issues to contend with" ${ }^{\prime}$. According to Beville, terror is in fact a form of metaphysical expression in today's literature.

Over the past few years, the potentialities of contemporary Gothic have been further reconsidered through vivid arguments, as Catherine Spooner points out: this new genre "possesses a new self-consciousness about its own nature; it has reached new levels of mass production, distribution and audience awareness, enabled by global consumer culture; and it has crossed disciplinary boundaries to be absorbed into all forms of media." ${ }^{\prime}$ Contemporary Gothic is not preoccupied with the end of the world, but rather with the end of innocence, a concept that underlines the fact that Morton's novels are revisions of history through the process of haunting. In addition to this, it is relevant to make a reference to Kate's Morton narrative style, which promotes a concept of visual literature, featuring the voices of the past, hallucination and dream visions in the process of rewriting history.

In Kate Morton's works the house becomes more than a symbol; the mysterious, forgotten or abandoned house gains shape through daydream, a binding principle for the integration of thoughts.

In order to understand how the symbol of the house works in Kate Morton's writings, we might benefit from a detour through the work of Ruth Parkin-Gounelas. In her article Anacbrony and Anatopia: Spectres of Marx, Derrida and Gotbic Fiction she underlines the fixation of Gothic fiction on anatopias: "the repetition on other forms of this house, as well as of its contents: its villains, incestuous relationships, disembodied parts, and above all, the buried secrets of its origins." 7 This preoccupation for anatopia is applicable to the symbol of the house, which becomes more than a mirror to a character's psychology or a portal for encountering a family history.

Spaces filled with past and dark secrets bring to the forefront a new portrayal of the house. The role of the house in constructing identities is not presented in the traditional Gothic manner but provides the viewer a realistic image of the revival of the past. Novels like The House at Riverton, The Secret Keeper, The Lake House, The Forgotten Garden and The Distant Hours problematize the way in which the house encapsulates memories - always revived by the need to discover a secret. As an expression of what Catherine Spooner reveals as "the desire for plenitude, for interiority and depths", the house is now being integrated like a shadow of what the house used to be for Gothic literature in the last two centuries.

Without succumbing the symbolism of the house, David Punter states that within the Gothic mansion "one may be subjected to a force that is utterly resistant to the individual's attempt to impose his or her own order." Arguing in favor of the house as a labyrinth, Punter associates it with the map and the loss of direction. The loss of direction indicates also a sign of antiquity, of a life that is gone, but keeps reappearing in the subconscious.

In one of his theories, Dani Cavallaro identifies the image of the labyrinth as one of the complexities of the literary text: "Gothic figures of fragmentation, disorder and excess are frequently mirrored by textual bodies that reject organic unity in favor of a multiplicity of viewpoints and styles, pastiche, collage and quilting." ${ }^{10}$

Confirming Cavallaro's theory, Morton's novels incorporate the symbol of the labyrinth towards a continuous revival of 
the past and its burdens, overstepping at the same time measureless boundaries, including those of the narrative itself.

This outlines a new condition for Morton's characters, a recalibration through the lenses through which anxieties are revealed by an ancient secret. All her writings follow the same pattern in terms of places: an old house is discovered after almost a decade and a concealed secret is discovered under its walls. The liminal imaginary of Morton's narrative evinces a commitment to exploring the new ways of organizing old realities.

\section{The Literature of Otherness - The House at Riverton}

Set in a period right before the First WWorld War, Morton's House at Riverton follows a cast of characters back in the 1920 s and in the present day. The mystery surrounds the death of a young poet, Robbie, in the summer of 1924 , at a society party that was held at Riverton. The only witnesses were the sisters Hannah and Emmeline and Grace, the house servant.

This narrative is filtered through the eyes of a ninety-eight year-old Grace; while living out her last days in a nursing home, she is visited by a young director who is making a film about the events of that summer. She takes Grace back to Riverton House, where her memories are brought into present time and the secret of Robbie's death will be revealed.

The novel attempts to solve the conundrum by using the voice of Grace for recalling old memories:

It was the Riverton drawing room. Even the wallpaper was the same.
Silver Studios'burgundy Art Nouveau, 'Flaming Tulips', as fresh as the day the paperers had come from London. A leather chesterfield sat at the centre by the fireplace, draped with Indian silks just like the ones Hannah and Emmeline's grandfather, Lord Ashbury, had brought back from abroad when he was a young officer [...] Even now, some eighty years later, I remember the sound of the drawing-room clock. The quietly insistent way it had of marking the passage of time: patient, certain, cold- as if it somehow knew, even then, that time was no friend to those who lived in that house. ${ }^{11}$

The combination of flashback and flashforward, of the past mode and re-telling is reinforced by the memories Grace mentally addresses.

The haunting of Robbie's unsolved mysterious death is a projection brought on by using glimpsed images of the remaking of the house of Riverton, images that recur to signify and to revive feelings from the past, with the purpose of encoding the house symbolically:

The room was at the back of the house and very high. I could see all the way past the rose garden, over the trellises and to the south fountain. Beyond, I knew, lay the lake and, on the other side, the village and the cottage in which I had spent my first fourteen years. I pictured Mother, sitting by the kitchen window, where the light was best, her back curled over the clothing she darned. ${ }^{12}$

The mystery behind this picture recalls forgotten memories, bringing them back 
to the present time. The overall atmosphere of secrecy contributes to the Neo-Gothic tropes. Images of the house reinforcing Grace's past and present trauma intensify her feelings of doom. The way in which the house is being envisioned suggests the representation of the self as Riverton house.

The narrative translates all the symptoms into narrative techniques, following the same pattern: memory loss transforms into ellipses and blackouts shape into ellipses. Correlating the images of the young and the almost senile Grace allows the mirroring of Riverton house and the events that took place there.

One of the most important aspects in this novel is how one of the Gothic's narrative techniques permeates it: transgression. Following one of David's Punter theories, which associates transgression with the spectacle of the female protagonist, we may apply the same pattern to the use of this technique in this novel. Grace's character encapsulates both the questioning of identity and the transgression of borderlines. ${ }^{13}$ The incorporated avatars of the classical Gothic create a prolific landscape for a mixture between the past and the present, the stories representing a labyrinth of sorts.

The labyrinth in this novel provokes a sense of otherness. The reader once again finds himself within a vicious maze, circumscribed within the borders of secrets and mysteries. There may be a compromise following this path, a sense of desire combined with the immediate need for unravelling the truth, along with the other. In this respect, my interpretation follows the observation of Catherine Spooner, regarding the function of space as a dividing frame between the outside world and the house: "The space allows the experience of the uncanny to be played out: one is only permitted to comprehend one's surroundings, to feel the comfort of recognition, once one has reached a position guaranteed to provoke a sense of otherness and personal risk." ${ }^{14}$ In this context, the other can be either Grace or anyone who enters her story. Spooner explains her statement through the idea that one can be a part of the story as long as one crosses the border of the mysterious space.

\section{A Book of Fairytales - The Forgotten Garden}

$\mathrm{I}$ n Morton's Forgotten Garden, the protagonist, Cassandra, on her grandmother's death, Nell, comes into an unexpected inheritance, Cliff Cottage and its forgotten garden. The location is what surprises Cassandra, since the cottage is located on the Cornish coast, in England.

The wound that breeches the history about the narrator's family is the revealed truth about the Mountrachet family and their ward Eliza Makepeace, a writer of dark Victorian fairytales. Cassandra's inheritance includes also a book by Eliza Makepeace. Following the steps of her grandmother on a quest to find out the truth about their history, she discovers on the grounds of Blackhurst Manor the forgotten garden of the book's title and is able to unlock the secrets of the book of fairy tales: "and it was something about the book itself. It exercised the same compulsion over Cassandra that it had when she was ten years old and had first discovered it downstairs in Nell's flat."15

As a result of this, Cassandra discovers that Nell had been abandoned on a ship headed for Australia in 1913. On her 
arrival, she was taken in by the dockmaster and his wife and raised as their own. On her twenty-first birthday, they told her the truth and Nell went back to England to find out the truth about her real identity. Her quest led her to Blackhurst Manor on the Cornish coast and the secrets of the doomed Mountrachet family. Hence, the truth was discovered by Cassandra during her journey to Blackhurst Manor.

The process of shattering and fragmentation is set up from the first description of Nell's house in England:

A thin, cracked concrete path ran up one side. There was a front door, way up too, but someone years ago had enclosed stairway so that the entrance was obscured, and Lesley said no one ever used it. Nell liked it that way, she added: it stopped people from dropping in unexpectedly, thinking they were welcome. The gutters were old and wonky, and in the centre was a large rust-rimmed hole which must've let through buckets of water when it stormed. ${ }^{16}$

The hole may be interpreted as the mouth of a labyrinth that will lead into Nell's story. Just as the house and its surroundings expand, so the narrative keeps expanding itself.

The fear of violation is emphasized also by the trope of ruins: "The house has been neglected, but its position on the Paddington slopes behind old Plaza theatre had felt about as close to home as Nell could get. And the house has rewarded her faith, had even provided her with a new income." ${ }^{17}$

The process of obliteration happening to the Blackhurst Manor creates anxiety, the only manner of controlling fear being the performative reality of the narrative, which creates more gaps that need to be filled through the act of story-telling:

A stone path led beneath an arbor of ancient roses with arthritic joints. The temperature cooled as they crossed the garden's threshold. The overall impression was one of darkness and gloom. And quiet, an odd, still quiet. Even the noise of irrepressible sea seemed dull in here. It was as if the grounds within the stone wall were asleep. Waiting for something, or someone, to wake them." ${ }^{\text {18 }}$

The Blackhurst Manor is a world of words, in which the lost characters cannot escape. This garden is itself a labyrinth of sorts, as a thread spooling into the revival of old memories.

Just as the house expands into indefinite forms, capturing landscapes from the past and revitalizing them through present memories, Nell herself films the explorations of the house through the lenses of both a child and an old woman:

Then before her eyes the garden changed. Weeds and brambles, decades in the growing, receded. Leaves lifted from the ground, revealing paths and flowerbeds and a garden seat. Light was permitted entry once more, tossed dappled across the surface of the pound. And then she was in two places at once: a sixty-five-year-old woman with a sore knee, clinging to a rusty gate, and a little girl, long hair plaited down her back, sitting on a tuft of soft, cool grass, toes dangling in the pound. ${ }^{19}$ 
The most useful illustrative framework for such a logic can be associated with David Punter's theory on the symbolism of the house, which emphasizes the force within a Gothic house, inside which one may be absorbed without imposing his or her own order. ${ }^{20}$

The gate plays the role of a portal, where thematic concerns mirror one another:

Cassandra stepped through the gate and was struck once more by the strange, heavy silence that lay around the cottage. There was something else, too, something she felt but couldn't name. and odd sense of collusion. As if but entering the gates she was agreeing to a pact whose rules she did not know. ${ }^{21}$

The Gothic symbols emerge in a nostalgic dream of a return to a long-forgotten past, Gothic always harkening back to another time. As David Punter points out, chronology represents an obstacle in a universe where the past has never been a present. ${ }^{22}$ Time represents a mythical point of reference and at the same time an impossible referent:

The house seemed to be listening, waiting to see what she would do. She ran her hand lightly along the inside wall. My house, she said softly, This is my house. The words pressed dully into the walls. ${ }^{23}$

\section{Beneath the Castle's Walls - The Distant Hours}

Tn Kate Morton's Distant Hours, the Iprotagonist, Edie Burchill finds herself on a journey to Milderhurst Castle, after receiving a long lost letter. Midelhurst Castle is the place where the Blythe sisters live and where her mother was billeted 50 years before as a 13-year old child during the Second World War. The elder Blythe sisters are twins and have spent most of their lives looking after the third and youngest sister, Juniper, who has not been the same since her fiancé jilted her in 1941. Inside the decaying castle, Edie begins to unravel her mother's past.

Midelhurst Castle represents in this novel the psyche itself: the castle has become the motif which stages the haunted self. The process of fragmentation is played not only by the description of the house, but also by the representation of the split selves of the Blythe sisters:

For there they were, half a mile along the road, right where I'd imagined they might be. Rising from the brambles, a set of tall iron gates, once grand but listing now at broken angles. Leaning, one towards the other as if to share a weighty burden. A sign was hanging on the small stone gatehouse, a rusted sign that read, Midelhurst Castle. ${ }^{24}$

The clear correlation between the sisters' mysterious personalities allows the flawless mirroring of the castle. Another reference to David Punter's study can be inserted here: it refers to the Gothic features of the castle. The starting hypothesis of the castle is that it seems to distort perception, acting like "unreliable lenses through which to view history and from the other side of which may emerge terrors only previously apprehended in dream." 25

On one hand, the castle may be interpreted as a place of security for the Blythe 
family, whose secret is kept between its walls. On the other hand, we may interpret Midelhurst as a place where the sisters have been locked away from ordinary life. The labyrinth in the house forces the sisters to internalize the secret, by not allowing Edie in the first place to take a tour on her own. We may apply Baudrillard's theory regarding the quest for an absolute self. According to him, the postmodern subject, which, in this case, is Juniper, has devoured her own double, disappearing into her own story and being driven by her sisters' will. ${ }^{26}$ She has isolated herself from language and from outer world.

Can Midelhurst Castle embody the (de)construction of the secret itself? As a place that entraps images of the maze, it is thus caught in the same attempt to renew the topos, presenting it as a projection or an embodiment of the psyche. According to Anne Williams, the house makes concrete the power that gives right to action within society. The property gives to the Blythe sisters the power to keep Juniper and her mystery inside its walls. Midelhurst Castle also enables strangers to investigate the sisters' lives, since they accept visitors only following a strict schedule. In this configuration, Edie plays the role of "the other", following her female curiosity and her desire for knowledge.

The declared boundaries of the castle create the possibility of transgressing all of them. Midelhurst Castle has the function of an enclosing space, its secrets being defended from the outside world. The events of its own historical development are embodied by the castle's structure, as well as incorporated by the Blythe sisters, as Edie reflects:

The characters of the castle had come to life to me that afternoon; they seeped beneath my skin as I read and I now felt that I had known them all forever. That although I'd stumbled upon the village of Middlehurst by accident, there was a rightness to my being there. I'd experienced the same sensation when I first read Wuthering Heights and Jane Eyre and Bleak House. As if the story were one I'd already known , that it confirmed something I'd always suspected about the world: that it had sat in my future all along, waiting for me to find it. ${ }^{27}$

\section{A Portal to Wilderness -}

\section{The Lake House}

$\mathrm{T}$ he Lake House's plot is also structured according to the ramifications of a family tree. The tale of the Edevanes family elucidates the disappearance of their youngest child, eleven-month-old Theo; one midsummer's eve, after a beautiful party drawing hundreds of guests to the estate has ended, the Edevanes discover that their child has vanished without a trace. $\mathrm{He}$ is never found, and the family is torn apart, while the house is abandoned.Decades later, Alice, the older child of the Edevanes is living in London, having enjoyed a long successful career as a novelist.

In The Lake House, female subjectivity is represented by the female character, Sadie Sparrow, a young detective in the London police force, who is staying at her grandfather's house in Cornwall and whose curiosity is sparked while she takes a walk out one day and stumbles upon the old Edevane estate, which is now crumbling and covered with vines.

From its threshold, Edevane estate imprisons us within its landscapes: 
A strip of unruly yew trees ahead now re-presented itself as a hedge, neglected and wild, but a hedge nonetheless; on the northern horizon between two dense clumps of wildflowers, she could make out what appeared to be the span of a bridge; the broken gate she'd climbed through no longer seemed a rudimentary division between two natural spaces but an overrun border between civilization and the wilderness. Which meant this plot of land she traversed wasn't an uncultivated field, but a garden. At least, it had been one. ${ }^{28}$

The Lake House may be regarded as a Gothic-postmodernist work, which has to do with explorations of self and reality, by recreating the experience of an unsolved mystery, starting from an immortalized amount of time. The inversion of time and space is suggested by the description of one of the house's rooms, which "seemed frozen, its contents suspended, as if even the air, that most relentless of all elements, had been shut outside, as if it would be difficult to breathe inside. There was something else, too. Something that suggested the room had been that way for a long time." ${ }^{29} \mathrm{Al}-$ ice, as we know from reversing the inverted narrative in order to complete the story, realizes the fear of what had happened and seeks escape by moving to London. Nevertheless, she is continuously haunted by her past and therefore decides along with Sadie to unravel the secret of her little brother's mysterious disappearance.

The past inhabits the place from another time when Sadie discovers the house and it seems that a secret awaits to be unraveled once the portal to the past is open.
The lake's surface plays the role of a mirror, in which both the present and the past are encountered. While the lake reflects a need for its secret to be discovered, its image is already split from a divided self:

The lake's flat surface glistened in a secretive, slatey way and Sadie suddenly felt every bit of intruder she was. It was hard to say what made her so certain, but as she turned to leave, ducked through the hole in the yew and started chasing the dogs home, she knew, in that twist-of-the-gutway a police detective had better hope she developed, that something terrible had happened in that house. ${ }^{30}$

\section{A Meta-Mystery - The Secret Keeper}

$\mathrm{T}$ he Secret Keeper may be considered a meta-mystery, following Maria Beville's theory. The mystery is based on Laurel's confession, a sixteen-year-old girl, who is hiding out in her childhood tree house, dreaming of her future, when she witnesses a murder. ${ }^{31}$ Finding herself overwhelmed by the shadows of the past, Laurel returns from London to her family home in order to assemble the missing pieces of the crime she witnessed as a child.

Morton recreates a Gothic landscape of multiplicities, a house where reflections proliferate:

The house, she'd explained to them many times, had spoken to her, she'd listened and it turned out they'd understood one another very well indeed. Greenacres was an imperious old lady, a little worn, to be sure, cranky in her own way- but who wouldn't be? The 
deterioration, Dorothy could tell, concealed a great former dignity. The house was proud and she was lonely, the sort of place that fed on children's laughter, and a family's love, and the smell of rosemary's lamb roasting in the oven. ${ }^{32}$

Numerous memories emerge from this house, from a world inscribed by a language that is puzzling due to its delusive nature. The narrative lingers on ancient elements, the embodiment of family history, interposed between the outside world of reality and the inside world of the house, as Christine Berthin assumes. ${ }^{33}$

In this novel, the condition of the house reflects a frozen moment, reminiscent of the Gothic in terms of fragmentation and degradation.

The derealization of the landscape is suggested in the fairytale atmosphere:

Rural England, a farmhouse in the middle of nowhere, a summer's day at the start of the nineteen sixties. The house is unassuming: half-timbered, with white paint peeling gently on the western side and clematis scrambling up the plaster. The chimney pots are steaming and you know, just by looking, that there's something tasty simmering on the stove top beneath. It's something in the way the vegetable patch has been laid out, just so, at the back of the house; the proud gleam of the leadlight windows; the careful patching of the roofing tiles. ${ }^{34}$

The mazed image of the house itself reflects an enclosure in space, making the mind itself feel imprisoned.

\section{Clichés, Anachronisms and Fragmentation}

O hristine Berthin concedes that clichés, anachronisms and literalized metaphors go against the linearity of a text, signaling the presence in language of a linguistic other. ${ }^{35}$ This other appears in Kate Morton's novels as a transitory window. Unspoken secrets control both previous and current generations of characters and the mystery carried by the other is conveyed without being stated.

Following the same line for Morton's novels in terms of clichés, we must revisit one of Christine Berthin's conclusions: "The cliché is the very figure of haunting. In its discordant mode, it raises the shadow of a past that resists integration in the present of narration." ${ }^{36}$ The lingering trace of Gothic ancestry in these novels allows the writer to pitch the past against the present.

In Morton's novels, repetition and temporal confusion blurs the present's limits. Following another of Christine Berthin's theories, we may assume that the distortion of chronology affects subjectivity, since the characters are not contemporary with themselves and are influenced by the past's burdens. ${ }^{37}$ As readers, we are confronted with an anti-Bildungsroman in which the progress is teased by the unpredictable need for escaping the present and reviving the past.

The secret in Morton's novels no longer represents a refuge for the integration of the characters, therefore there is no internal coherence for the subject, as David Punter suggests. ${ }^{38}$ The identity of the subjects in these narratives has no armor beyond the (de)construction of the text, the 
secret itself having the role of emptying the subject.

The house has a connection to the secret, by means of the fragmentation of temporalities. In contemporary Gothic the house entraps the concept of the other. The inside world of the house needs to be constructed by the revitalization of its memories; otherwise, the secret will never be revealed. This need for revival has led to the emergence in Neo-Gothic of an auxiliary world that builds itself, by putting together the pieces of a lost past. Otherness triggers in us not only a Gothic inclination towards the past, but also a compulsion towards the present, inside which solved mysteries take us out of the maze.

These texts suspend meaning in the blurriness of language, jubilations and interruptions. This leads us to Roland's Barthes concepts of writerly and readerly text. The term "writerly" is used for characterizing an emphasis on the elaborate use of language, while "readerly" demands no effort in understanding a novel's meaning. These terms may be antithetically applied to Morton's novels from a rather different perspective, from which the reader has to complete the narrative with his own reflections. ${ }^{39}$ The alternation of temporal plans in these novels reflects anxieties, tensions and imbalances.

The gliding between past and present time also involves the transgression of some restraints by our own perception on the other. The impact on developing identity by making use of the house is analyzed by Anne Williams, whose deems that the figure of the other is consistent throughout Male Gothic. There is an engine circled by the desire of blaming the female, "who has some will of her own and refuses to give it up." ${ }^{40}$ Williams's theory follows a psychoanalytic concept from Freud, based on the interpretation of a child separated too early from his mother, who remains in his unconscious "as she was experienced by the pre-Oedipal infant- as a supernatural, magical, spectral image of good or evil or both at once." ${ }^{* 1}$

Freud's theories, which have provided an authoritative framework for reading Gothic literature in the past two decades, may be applied to Morton's narratives in terms of conceptualizing the other. All the protagonists in Morton's novels are women susceptible of concealing secrets. Although all the other characters have the role of deviating the narrative, they do not represent key factors for the development of the story. We may assume that Morton's novels are all following the same pattern in terms of representing the female. Still, we must admit her heroines are endowed with the ability of revealing the secrets, most of the times on their own.

The ideology of Neo-Gothic in these novels composes a new frame for the burdens of this new genre, where memories, secrets and oblivion are resolved inside a labyrinth, whose substantial role is to underline the vulnerabilities of time. The narrative techniques of creating temporal distances inside of the spreading present unlock the labyrinth, where possibilities of reconciliation between the past and the present are infinite.

Through the incorporation of horror, mystery, history and otherness and the use of narrative techniques which inspire terror, temporality and subjectivity are reversed in Morton's novels. The hybridization of the multiple facets of Neo-Gothic literary explorations maintains the focus of terror on different levels simultaneously. 


\section{Conclusions}

A balanced approach in Kate's Morton novels is a necessary step towards understanding the concept of Neo-Gothic, as it is encapsulated in her writings. The exploration of the past and its burdens on the present are key symbols in these novels, being underlined by unraveling a secret beneath the walls of a labyrinthic house. The author's emphasis is on this particular motif. At the level of fictional and narrative technique, her writings play on circularity, gaps and fragmentation.

The narrative deployment of the Gothic possesses a value marked by the other: the representations of the other in Neo-Gothic texts lead to the conclusion that the notions of identity need to be completed with a remaking of the self as a stranger. The past becomes, thus, a constant language of consciousness for anyone who tries to put all the missing pieces together.

The essence of Morton's writings is based on the legacies of the Gothic revival, but her narrative ability of suspending both meaning and limitation in the present, in order to encapsulate a vision of the past, is the new twist on this genre.

I would tie these elements to the conclusion of my paper, stating that the dissolution of Gothic can be seen as a revival of the Neo-Gothic, Kate Morton representing one of the authors whose contribution is major in developing this genre. To sum up, Kate Morton's works, by displaying a fascination with the otherness, take Gothic to a more transgressive level, where all the past centuries' motifs and symbols are revived.

\section{WORKS CITED}

Roland Barthes, S/Z, New York, Farrar, Stauss, Giroux, 1970.

Jean Baudrillard, Symbolic Exchange and Death (Tr. Mike Hamilton Green), London, Sage, 1993.

Christine Berthin, Gothic Hauntings, Melancholy Crypts and Textual Ghosts, London, Palgrave MacMillan, 2010. Maria Beville, Gothic Postmodernism. Voicing the Terrors of Postmodernism, New York, Rodopi, 2009.

Dani Cavallaro, The Gothic Vision: Three Centuries of Terror, Horror and Fear, New York, Continuum, 2002. Lynda Dryden, The Modern Gothic and the Literary Double, London, Palgrave MacMillan, 2003.

Kate Morton, The House at Riverton, London, Pan Books, 2007.

Kate Morton, The Forgotten Garden, London, 2008, Pan Books.

Kate Morton, The Distant Hours, London, Pan Books, 2011.

Kate Morton, The Lake House, London, Pan Books, 2016.

Kate Morton, The Secret Keeper, London, Pan Books, 2013.

Ruth Parkin-Gounelas, Anachrony and Anatopia: Spectres of Marx, Derrida and Gotbic Fiction, in Ghosts: Deconstruction, Psychoanalysis, History, Peter Buse and Andrew Stott eds, New York, MacMillan, 1999.

David Punter, Glennis Byron, The Gothic, Carlton, Blackwell Publishing, 2004.

Catherine Spooner, Contemporary Gotbic, London, ReaktionBooksLtd, 2006.

Anne Williams, Art of Darkness A poetics of Gothic, Chicago, The University Press, 1995.

\section{Notes}

1. Anne Williams, Art of Darkness A poetics of Gothic, Chicago, The University Press, 1995, p.21.

2. Catherine Spooner, Contemporary Gothic, London, ReaktionBooksLtd, 2006, p.10. 
3. Lynda Dryden, The Modern Gotbic and the Literary Double, London, Palgrave MacMillan, 2003, p.1.

4. Catherine Spooner, op. cit., p. 10.

5. Beville Maria, Gothic Postmodernism. Voicing the Terrors of Postmodernism, New York, Rodopi, 2009, p. 49.

6. Catherine Spooner, op.cit, p. 23.

7. Ruth Parkin-Gounelas, Anachrony and Anatopia: Spectres of Marx, Derrida and Gothic Fiction, in Ghosts: Deconstruction, Psychoanalysis, History, Peter Buse and Andrew Stott eds, New York, MacMillan, 1999, p. 131.

8. Ibidem, p. 26-27.

9. David Punter, Glennis Byron, The Gothic, Carlton, Blackwell Publishing, 2004, p. 262.

10. Dani Cavallaro, The Gothic Vision: Three Centuries of Terror, Horror and Fear, New York, Continuum, 2002, p. 211.

11. Kate Morton, The House at Riverton, London, Pan Books, 2007, p. 12-13.

12. Ibidem, p. 23.

13. David Punter, op. cit., p.26-27.

14. Catherine Spooner, op. cit., pag. 51.

15. Kate Morton, The Forgotten Garden, London, 2008, Pan Books, p. 111.

16. Ibidem, p. 33.

17. Ibidem, p. 72.

18. Ibidem, p. 259.

19. Ibidem, p. 302.

20. David Punter, Glennis Byron, op. cit., p. 262.

21. Kate Morton, The Forgotten Garden, p. 361.

22. Christine Berthin, Gothic Hauntings, Melancholy Crypts and Textual Ghosts, London, Palgrave MacMillan, 2010, p. 67.

23. Kate Morton, The Forgotten Garden, p. 361.

24. Kate Morton, The Distant Hours, London, Pan Books, 2011, p. 26.

25. David Punter, Glennis Byron op. cit., p. 260.

26. Jean Baudrillard, Symbolic Exchange and Death (Tr. Mike Hamilton Green), London, Sage, 1993, p. 101.

27. Kate Morton, Distant Hours, p. 52.

28. Kate Morton, The Lake House, London, Pan Books, 2016, p. 36.

29. Ibidem, p. 43.

30. Ibidem, p. 43.

31. Maria Beville, op. cit., pag. 100.

32. Kate Morton, The Secret Keeper, London, Pan Books, 2013, p. 51.

33. Christine Berthin, op. cit. p. 66.

34. Kate Morton, The Secret Keeper, p. 3.

35. Christine Bertine, op. cit., p. 56.

36. Ibidem, p. 69.

37. Ibidem, p. 67.

38. Ibidem, p. 68.

39. Roland Barthes, $S / Z$, New York, Farrar, Stauss, Giroux, 1970.

40. Anne Williams, op. cit., pag. 114.

41. Ibidem, pag. 114. 